OSEANOLOGI DAN LIMNOLOGI DI INDONESIA

Online ISSN: 2477-328X

Akreditasi RISTEKDIKTI No. 21/E/KPT/2018

http://jurnal-oldi.or.id

\title{
Abrasi dan Sedimentasi Pantai di Kawasan Pesisir Kota Bengkulu
}

\author{
M. Hasanudin dan Edi Kusmanto
}

Pusat Penelitian Oseanografi - Lembaga Ilmu Pengetahuan Indonesia

E-mail: m.hasanudin2014@gmail.com

Submitted 19 March 2018. Reviewed 4 May 2018. Accepted 16 December 2018

DOI: 10.14203/oldi.2018.v3i3.197

\begin{abstract}
Abstrak
Energi gelombang yang bekerja di perairan pesisir Kota Bengkulu sangat kuat, kondisi ini menimbulkan abrasi dan sedimentasi. Tujuan penelitian ini adalah untuk mengidentifikasi proses-proses yang terkait dengan abrasi dan sedimentasi di kawasan pesisir Kota Bengkulu. Metode penelitian yang dilaksanakan adalah dengan melakukan pengukuran batimetri, arus, kekeruhan, pasang surut dan gelombang. Hasil penelitian menunjukkan proses abrasi pantai di Pesisir Kota Bengkulu terjadi akibat dua faktor utama, yaitu hempasan gelombang yang intensif pada kaki tebing pantai dan curah hujan tinggi. Kondisi tersebut memperlemah ikatan material pembentuk pantai pada kaki tebing. Sedangkan sedimentasi terjadi akibat adanya suplai sedimen yang berasal dari material hasil runtuhan tebing pantai yang terbawa oleh arus di Perairan Pesisir Kota Bengkulu dan juga dari sungai Jenggalu dan Sungai Air Bengkulu.
\end{abstract}

Kata Kunci: abrasi pantai, sedimentasi, gelombang, Kota Bengkulu, transpotasi sedimen

\section{Abstract}

Coastal Abrasion and Sedimentation Kota Bengkulu Coast Area. Coastal environment of Kota Bengkulu is typified by strong wave energy, which caused coastal abrasion and sedimentation. This paper intends to discuss the abrasion and sedimentation processes in the coastal area of Kota Bengkulu. Bathymetry survey has been employed to measured the depth of ocean floor, together with turbidity of water, and tide and wave currents. The erosion in the coastal Kota Bengkulu occurred as a result of the strong waves which hit coastal cliffs intensively and high rainfall conditions that weaken the bond-forming material at the foot of the cliff coast. On the other hand, sedimentation occured due to the supply of sediment from the collapsed material of the coastal cliffs that are transported by the current in the Coastal Waters of Kota Bengkulu together with Jenggalu River and Air Bengkulu River.

Keyword: Coastal abrasion, Sedimentation, Wave, Kota Bengkulu, Sediment trasportation

\section{Pendahuluan}

Kota Bengkulu adalah ibukota Provinsi Bengkulu, secara geografistasi terletak pada koordinat $3^{\circ} 45^{\prime}-3^{\circ} 59^{\prime}$ Lintang Selatan dan $102^{\circ} 14^{\prime}-102^{\circ} 22^{\prime}$ Bujur Timur. Posisi geografis tersebut terletak di pantai bagian barat Pulau
Sumatera yang berhadapan langsung dengan Samudera Hindia. Kota Bengkulu mempunyai lingkungan pantai yang berhadapan dengan gelombang yang kuat, yang dipengaruhi oleh swell dan diperkirakan menimbulkan abrasi alami pantai akibat gelombang besar tersebut. Abrasi alami pantai atau abrasi pantai ini berpotensi untuk 
menimbulkan sedimentasi di sepanjang garis pantai serta suplai sedimen yang besar dari DAS yang terletak di sekitar Kota Bengkulu (http://infokotakita.blogspot.co.id/2013/09/wilaya h-kota-bengkulu.html).

DAS Bengkulu merupakan salah satu DAS di Indonesia yang mengalami permasalahan abrasi permukaan (lahan). Kemajuan pembangunan dan peningkatan laju pertumbuhan penduduk yang bermukim di sepanjang DAS Bengkulu. Kondisi ini yang menyebabkan terjadinya pemanfaatan dan pengelolaan DAS yang sangat intensif baik untuk pengembangan permukiman maupun pengembangan lahan. Alih fungsi lahan yang tidak terkendali, disamping sebagai pemicu terjadinya abrasi permukaan juga menjadi penyebab banjir dengan angkutan sedimen konsentrasi tinggi. Fenomena pendangkalan di sekitar muara Sungai Bengkulu disamping disebabkan oleh transpor sedimen dari arah pantai, juga ditengarai disebabkan oleh transpor sedimen yang berasal dari erosi permukaan di DAS hulu (Tunas 2005).

Abrasi dan sedimentasi pantai sesungguhnya adalah suatu bentuk keseimbangan interaksi antara faktor-faktor oseanografi dan geologi di kawasan pesisir. Faktor-faktor oseanografi di antaranya adalah gelombang, pasang surut dan arus sedangkan faktor geologi antara lain adalah batuan penyusun pantai dan morfologi pantai. Pada kondisi faktor oseanografi lebih kuat daripada faktor geologi, maka pantai akan mengalami abrasi. Pada kondisi yang berbeda, yaitu faktor geologi lebih kuat daripada faktor oseanografi, maka pantai akan mengalami sedimentasi atau stabil (Morton 2004).

Fenomena gelombang yang mendominasi gerakan air dekat pantai adalah gelombang yang diakibatkan oleh angin lokal (Wind waves) dan gelombang panjang atau gelombang dengan frekuensi rendah (Low-frequency waves). Gelombang yang dihasilkan oleh angin lokal yang bertiup di sepanjang pesisir akan memindahkan energinya ke gelombang dengan dominasi arah gelombang sesuai dengan arah datangnya angin. Gelombang yang diakibatkan oleh angin lokal tersebut akan berupa gelombang acak yang mempunyai tinggi ataupun periode yang berbeda (Mei 1989).

Terdapat beberapa penelitian mengenai sedimentasi dan abrasi di Perairan Kota Bengkulu, di antaranya adalah Arifin et al. (2003) yang menyebutkan bahwa sedimentasi yang terjadi di Pelabuhan Pulau Baai berlangsung cukup cepat dan material sedimentasi berupa pasir yang berasal dari sekitar pantai dan penelitian ini diperkuat oleh hasil pemodelan yang dilakukan oleh Supiyati et al. (2011 dan 2013). Penelitian Suwarsono et al. (2011) mengenai abrasi Pesisir Bengkulu akibat gelombang menyebutkan bahwa kecepatan abrasi pantai antara $0.5 \mathrm{~m}$ hingga $2.5 \mathrm{~m}$ per tahun di bagian utara relatif lebih cepat di bandingkan di bagian selatan. Penelitian ini bertujuan untuk memaparkan kemungkinan proses abrasi dan sedimentasi di kawasan Pesisir Kota Bengkulu, Hasil penelitian ini diharapkan dapat digunakan sebagai tambahan informasi bagi pemerintah daerah dalam pembuatan kebijakan pengelolaan wilayah pantai.

\section{Metodologi}

Lokasi penelitian adalah Pesisir Kota Bengkulu diantara daerah Pondik Kelapa di sebelah utara dan Pelabuhan Pulau Baai di sebelah selatan. Pengambilan data lapangan dilakukan pada bulan Juni 2013.

Pengukuran arus dan kekeruhan air laut (backscatter) secara spasial dilakukan dengan Acoustic Doppler Current Profiler (ADCP) tipe $1200 \mathrm{kHz}$ di sepanjang jalur perahu yang bergerak dengan kecepatan antara 4-5 knot. Pengukuran pasang surut dan gelombang secara time series di satu titik dan dilakukan dengan RBR TWR 2050.

Single beam echosounder SyQwest Bathy 500 DF digunakan untuk pengukuran kedalaman perairan. Penentuan posisi dilakukan dengan menggunakan Garmin 276 C GPS. Semua peralatan disinkrosinasi waktunya terhadap waktu GPS Garmin 276 C. Selain itu GPS ini juga digunakan untuk tracking garis pantai.

Gelombang di perairan pesisir dapat direpresentasikan oleh gelombang signifikan dari satu titik pengukuran dengan mengestimasi gelombang tertinggi hingga gelombang terendah.. Persamaan untuk tinggi gelombang menurut Holthuisen (2010) adalah:

$$
H_{r m s}=\left(\frac{1}{N} \sum_{i=1}^{n} H^{2}\right)^{1 / 2}
$$

$H_{r m s}=$ root mean square of wave height

$$
H_{1 / 3}=\frac{1}{N / 3} \sum_{j=1}^{N / 3} H_{j}
$$

$H_{1 / 3}=$ Significance wave heigth 


\section{Hasil}

Secara umum, kondisi batimetri Perairan Pesisir Kota Bengkulu relatif datar dengan kemiringan kurang dari $1^{\circ}$ dengan kedalaman maksimum sekitar $65 \mathrm{~m}$ (Gambar 2). Daerah perairan yang lebih dangkal berada di sekitar Pantai Kota Bengkulu dan sekitar Pulau Tikus dengan kedalaman sekitar $25 \mathrm{~m}$. Sedangkan perairan yang lebih dalam berada di sebelah barat Pelabuhan Pulau Baai dengan kedalaman mencapai $65 \mathrm{~m}$.

Berdasarkan data yang terekam oleh RBR TWR 2050 sepanjang penelitian yang dilakukan tanggal 14 hingga 17 Juni 2013 diketahui tinggi gelombang berkisar antara 0,6 m hingga $1,2 \mathrm{~m}$, sedangkan energi gelombang yang terekam berkisar antara $300 \mathrm{~J} / \mathrm{m}^{2}$ hingga $1100 \mathrm{~J} / \mathrm{m}^{2}$ Energi gelombang dengan besaran di atas $400 \mathrm{~J} / \mathrm{m}^{2}$ berlangsung secara terus-menerus di sepanjang waktu penelitian (Gambar 3).

Arah dominan gelombang terutama berasal dari arah barat hingga barat daya $\left(240^{\circ}-270^{\circ}\right)$, yang merupakan laut lepas, Samudera Hindia. Arah gelombang ini membentuk sudut sekitar $30^{\circ}$ terhadap garis normal pantai sehingga sudut yang sedemikian ini akan menghasilkan arus sepanjang pantai dengan dominasi ke utara (Gambar 4).

Pola arus di perairan Kota Bengkulu selama penelitian (Gambar 5), menunjukkan adanya aliran massa air yang kontinu menuju ke selatan di daerah dengan batimetri yang lebih dalam dan ke arah lepas pantai. Secara umum arus di perairan ini menuju ke selatan. Keberadaan Pulau Tikus menyebabkan ada sebagian aliran massa air yang berbelok menuju ke Pelabuhan Pulau Baai. kemudian ketika aliran massa air ini terhalang oleh Pelabuhan Pulau Baai maka aliran ini dibelokan kembali ke arah utara. Selain itu diketahui pula adanya arus susur pantai menuju ke utara yang diakibatkan gelombang yang berarah $30^{\circ}$ terhadap garis pantai Kota Bengkulu. Arus susur pantai ini menjalar di perairan pesisir dekat pantai dengan variasi kecepatan arus antara $10 \mathrm{~cm} /$ detik hingga $70 \mathrm{~cm} /$ detik.

Data backscatter perairan pesisir Kota Bengkulu ditunjukkan pada Gambar 6. Skala warna biru menunjukkan bahwa perairan memiliki kekeruhan yang rendah sedangkan skala warna merah menunjukkan kekeruhan yang besar. Pada penampang kekeruhan A (daerah Pondok Kelapa) terlihat bahwa kekeruhan yang relatif besar (warna kuning hingga merah) berada di dekat dengan pantai, dari gambar juga terlihat bahwa semakin ke arah laut lepas kekeruhannya semakin rendah. Pada penampang B (Daerah Pantai Jakat) terlihat bahwa kekeruhan airnya sudah mulai bergerak menjauhi pantai, demikian pula yang terjadi pada penampang C (Daerah Pantai Panjang) dan penampang D (Daerah Pelabuhan Pulau Baai) terlihat bahwa kekeruhan yang relatif besar terlihat bergerak semakin jauh dari pantai. Hal menarik pada penampang $\mathrm{D}$ terlihat bahwa nilai kekeruhan yang besar berada di dekat pantai menyambung sampai dengan dasar perairan sehingga dapat dikatakan bahwa pada daerah ini sedang terjadi proses pengendapan material sedimen yang terbawa arus air (sedimentasi).

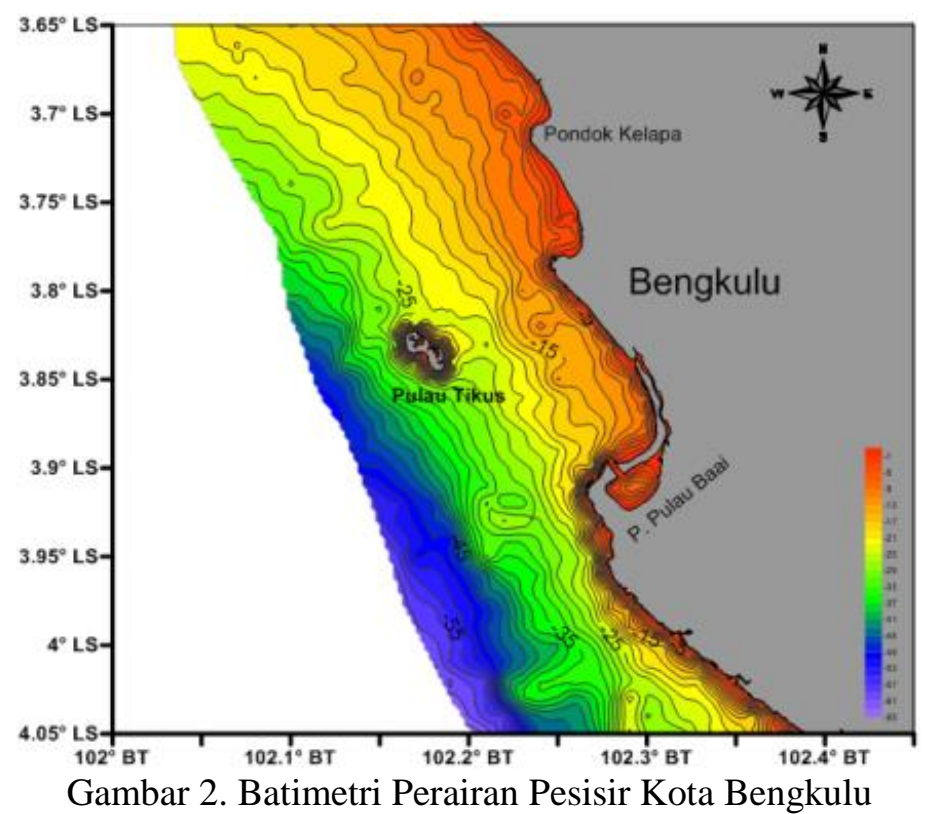

Figure 2. Bathymetric of Bengkulu Coastal Waters 

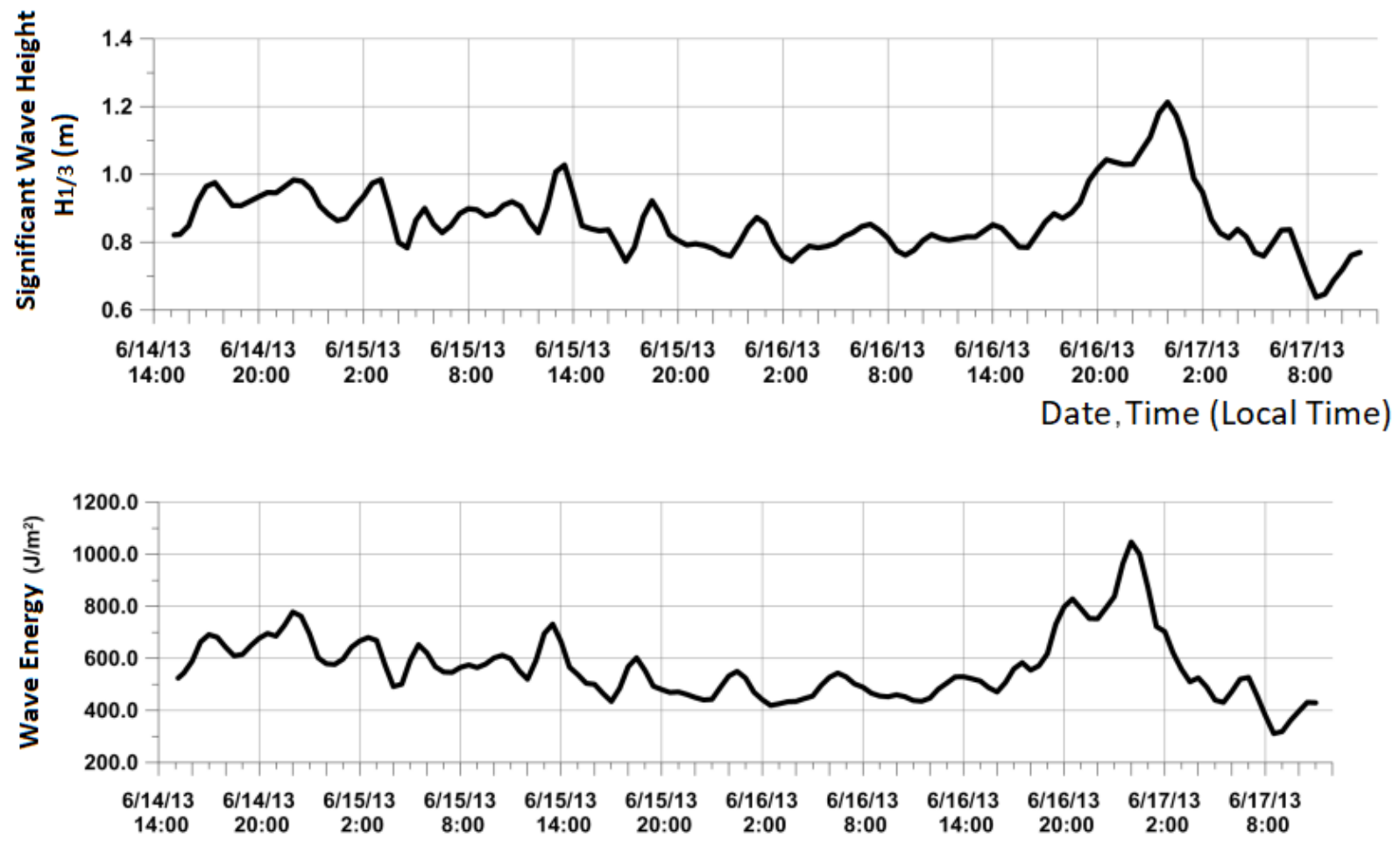

Date, Time (Local Time)

Gambar 3. Tinggi dan Energi Gelombang Perairan Pesisir Bengkulu bulan Juni 2013

Figure 3. Wave height and Wave energy of Bengkulu Coastal Waters in June 2013

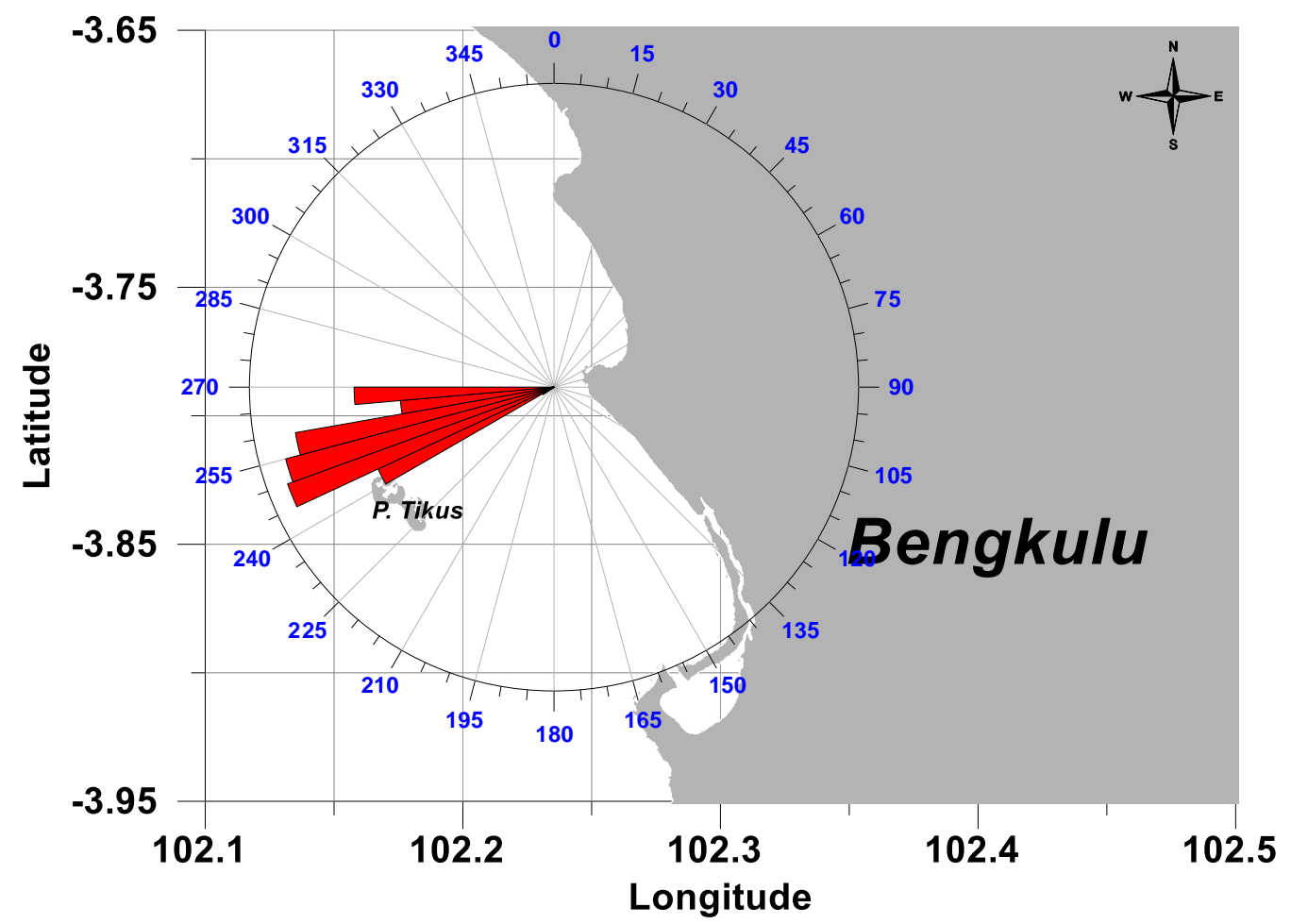

Gambar 4. Arah Datang Gelombang Perairan Pesisir Bengkulu bulan Juni 2013

Figure 4. Wave incident of Bengkulu Coastal Waters in June 2013 




Gambar 5 Pola arus Pesisir Kota Bengkulu bulan Juni 2013

Figure 5. Current pattern of Bengkulu Coastal Waters in June 2013

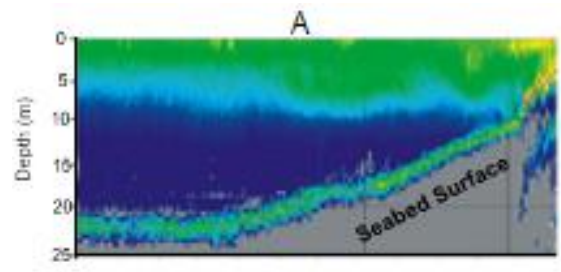

B

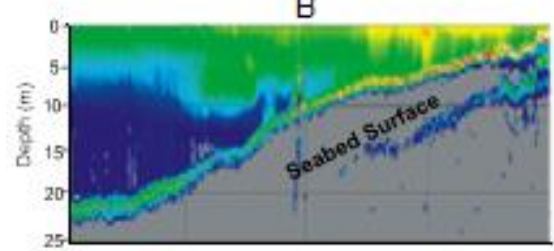

C

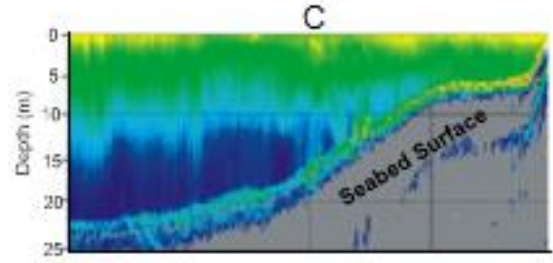

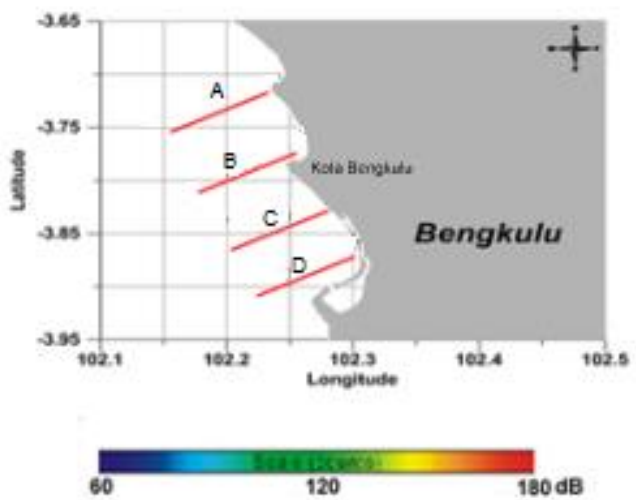



Gambar 6. Profil kekeruhan perairan berdasarkan data backscatter ADCP Figure 6. Turbidity profile base on ADCP backscatter data

\section{Pembahasan}

Gelombang adalah kekuatan paling dominan yang menyebabkan abrasi pantai. Secara khusus gelombang laut pecah pada kedalaman yang memiliki kisaran antara 1 hingga 1,5 kali ketinggian gelombang. Salah satu proses abrasi yang terjadi di pantai merupakan akibat dari aksi hidrolik, hempasan dan pengerusan oleh gelombang (Schwartz 2005). Frekuensi hantaman gelombang yang tinggi pada kaki tebing mempercepat abrasi dan menggerus kaki tebing yang dapat menyebabkan lapisan-lapisan material runtuh atau bergerak (Sunamura 1977).

Faktor lain yang mempercepat abrasi adalah air hujan. Air hujan dapat mengalir ke laut melalui sungai, permukaan tanah yang berupa air permukaan dan juga dapat merembes melalui poripori tanah yang berujung di kaki tebing. Rembesan ini melemahkan ikatan antara material-material 
pembentuk tebing pantai. Hal lain adanya sisipan air khususnya di sepanjang lapisan tanah yang mempunyai rekahan-rekahan dapat juga menyebabkan kerusakan tebing. Dengan demikian abrasi tebing disebabkan oleh dua proses yaitu penggerusan kaki tebing yang kemudian dilajutkan dengan runtuhnya tebing (Nott 1990).

Ketinggian gelombang maksimum di perairan pesisir Bengkulu tercatat sekitar $1,2 \mathrm{~m}$ dengan energi maksimum sekitar $1100 \mathrm{~J} / \mathrm{m}^{2}$. Komposisi batuan penyusun pantai di wilayah ini terdiri atas alluvium yang didominasi oleh lempung (Gambar 7). Kondisi gelombang yang relatif tinggi dan komposisi utama batuan alluvium merupakan faktor utama dari abrasi yang terjadi di Pesisir Pantai Kota Bengkulu akibat hantaman gelombang. Kondisi ini sesuai dengan apa yang dinyatakan oleh Carter (1988) bahwa pantai tebing dengan komposisi dominan lempung dapat digerus oleh gelombang dengan ketinggian antara $1 \mathrm{~m}$ sampai dengan $1,2 \mathrm{~m}$.

Selain akibat hantaman gelombang yang intensif, kerusakan pantai Kota Bengkulu juga diperparah oleh kondisi curah hujan yang tinggi. Berdasarkan tabel Schmidt - Ferguson Kota Bengkulu termasuk tipe curah hujan jenis A dengan sifat sangat basah karena curah hujan tahunan tinggi, rata-rata lebih besar dari 70 $\mathrm{cm} /$ tahun. Intensitas curah hujan rata-rata kota Bengkulu cenderung meningkat setiap tahun (Hadi et al. 2010). Semakin tinggi curah hujan maka semakin tinggi pula rembesan air hujan melalui pori-pori tanah yang berujung pada kaki tebing yang pada akhirnya akan melemahkan ikatan antara material material pembentuk pantai. Sisipan air tanah khususnya di sepanjang lapisan dan rekahan-rekahan juga bisa menyebabkan kerusakan tebing.

Salah satu daerah yang mengalami abrasi pantai yang cukup berat terjadi di daerah Pondok Kelapa seperti yang terlihat pada Gambar 7. Pantai di Kota Bengkulu mengalami kerusakan yang diakibatkan oleh abrasi pantai yang cukup serius dengan tingkat kemunduran garis pantai 2-5 meter per tahun (Suwarsono et al. 2011).

Material hasil abrasi akan masuk ke dalam massa air dan tertransportasi. Material yang tersuspensi ini direpresentasikan oleh nilai backscatter, semakin besar nilai backscatter menunjukkan besarnya material yang tersuspensi. Gambar 6 menunjukkan bahwa nilai kekeruhan yang relatif cukup besar dijumpai di sekitar Pantai Pondok Kelapa. Kekeruhan ini diperkirakan merupakan material runtukan abrasi pantai sekitar Pondok Kelapa. Sedangkan untuk Line 2 dan Line
4 (Gambar 6) adalah penampang kekeruhan daerah Sungai Air Bengkulu dan Sungai Air Jenggalu. Dari kedua penampang ini terlihat bahwa kekeruhan yang besar terdapat di daerah dekat pantai yang merupakan muara dari kedua sungai tersebut yang menunjukkan bahwa kedua sungai ini menyuplai material sedimen ke Perairan Pesisir Kota Bengkulu. Hal ini berkesesuaian dengan apa yang dinyatakan Tunas (2005) yang menyatakan bahwa alih fungsi lahan yang telah terjadi dengan tidak terkendali di DAS Bengkulu, disamping sebagai pemicu terjadinya erosi permukaan juga menjadi penyebab terjadinya banjir dengan angkutan sedimen konsentrasi tinggi.

Sesuai dengan pola arus yang diperlihatkan pada Gambar 5, terlihat bahwa aliran massa air akibat hempasan gelombang bersama dengan massa air tawar yang berasal dari muara sungai Air Bengkulu dan Air Jenggalu mengalir ke arah utara. Sebagai konsekuensinya, semua material hasil abrasi dan muatan sedimen dari sungai akan terbawa ke lepas pantai yang selanjutnya dibelokan ke selatan melalui perairan yang lebih dalam. Di wilayah bagian utara Pelabuhan Pulau Baai sebagian material tersuspensi tersebut ada yang terbawa terus ke selatan dan sebagian material tersuspensi tersebut dibelokkan ke timur dan terbawa kembali ke pesisir Pantai Panjang di utara Pelabuhan Pulau Baai dan di sekitar Pantai Jakata di utara pusat Kota Bengkulu.

Berdasarkan perbandingan antara garis pantai lama yang diambil dari data Bakosurtanal tahun 2002 dan pengukuran garis pantai dengan tracking GPS pada saat penelitian dilakukan diketahui bahwa daerah yang mengalami abrasi adalah Pantai Tapak Paderi (Pelabuhan lama Bengkulu) dan Muara Sungai Jenggalu serta daerah Pondok Kelapa. Daerah yang mengalami sedimentasi di pesisir Bengkulu adalah Pantai Panjang dan Pantai Jakat (Gambar 8).

Proses sedimentasi yang terjadi di Pantai Jakat, Pantai Panjang dan Pelabuhan Pulau Baai terjadi akibat adanya suplai material yang berasal dari abrasi di bagian utara daerah penelitian (Pondok Kelapa) dan ditambah suplai material yang lebih besar dari sungai Air Bengkulu dan Sungai Air Jenggalu. Partikel yang tersuspensi tersebut dibawa oleh arus yang bekerja di perairan Pesisir Bengkulu dan terendapkan di wilayah yang tenang atau ketika terjadi surut terendah atau saat pasang tertinggi. Pada perioda surut terendah dan pasang tertinggi arus akibat pasang surut mempunyai nilai minimum atau saat tenang saat gelombang mulai mereda. 


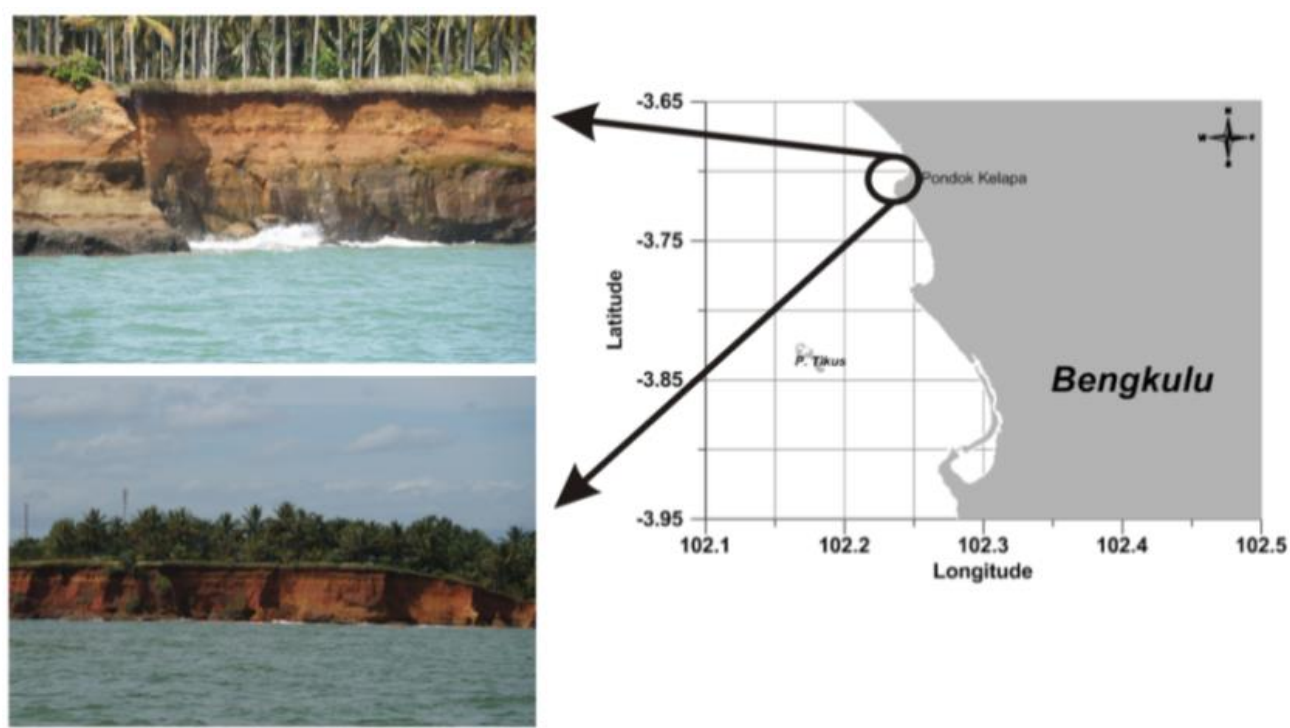

Gambar 7. Daerah yang mengalami abrasi pantai di Pondok Kelapa, sebelah utara Kota Bengkulu Figure 7. Abrasion area in Pondok Kelapa, Northern of Bengkulu City

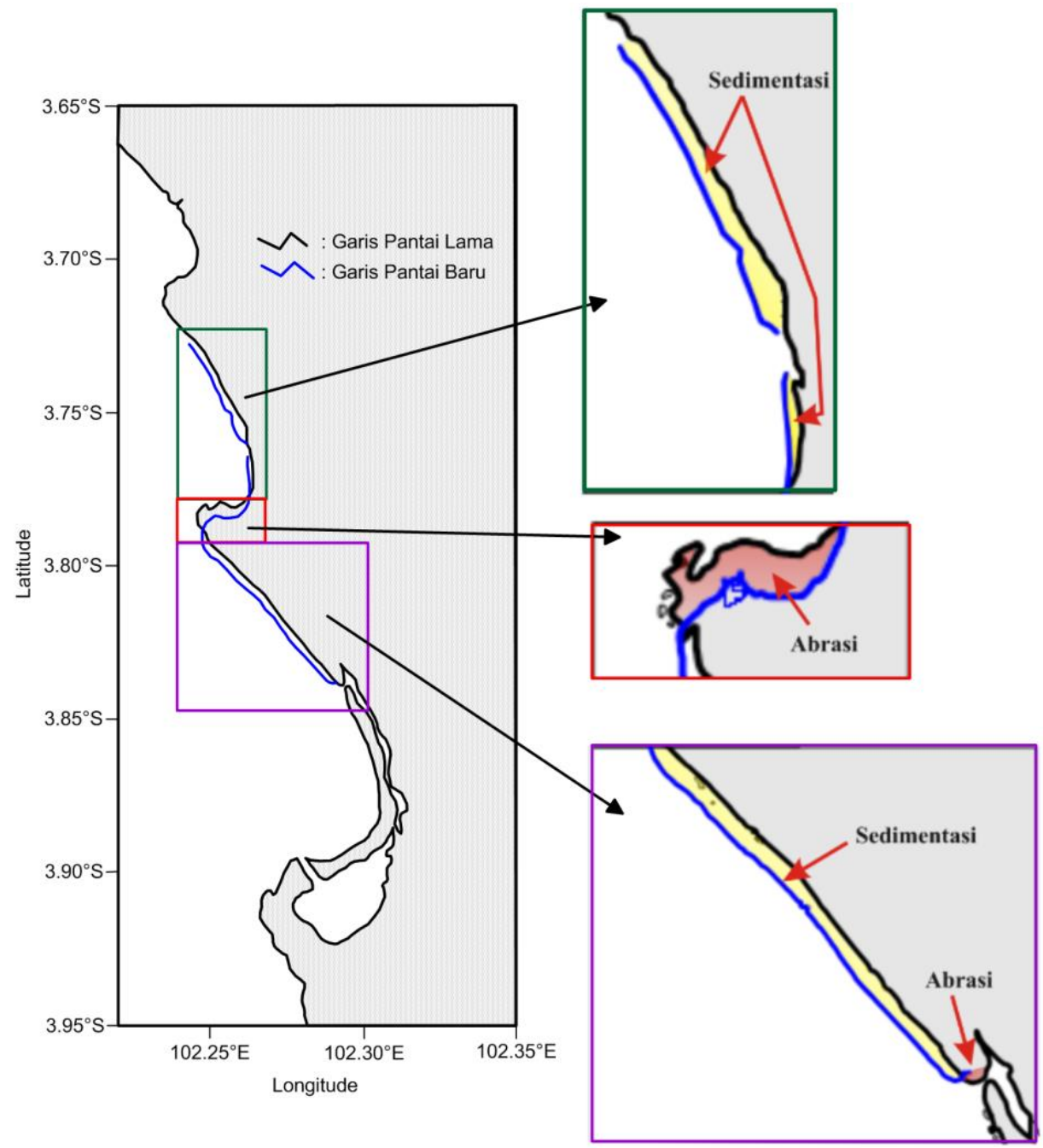

Gambar 8. Daerah terabrasi dan sedimentasi berdasarkan perbandingan Garis Pantai Bakosurtanal tahun 2002 dan tracking GPS bulan Juni 2013.

Figure 8. Abrasion and sedimentation area base on comparison between Bakosurtanal Coastline in 2002 and GPS tracking in June 2013 


\section{Kesimpulan}

Proses abrasi pantai di Pesisir Kota Bengkulu sangat dipengaruhi oleh hempasan gelombang yang intensif pada kaki tebing pantai dan diperparah dengan kondisi curah hujan tinggi yang memperlemah ikatan material pembentuk pantai pada kaki tebing. Sedangkan sedimentasi yang terjadi kemungkinan akibat adanya suplai sedimen yang berasal dari material hasil runtuhan tebing pantai yang tertransportasi oleh arus di Perairan Pesisir Kota Bengkulu dan juga dari sungai Jenggalu dan Sungai Air Bengkulu.

\section{Daftar Pustaka}

Arifin L, JP Hutagaol dan M Hanafi. 2003. Pendangkalan Alur Pelayaran di Pelabuhan Pulau Baai Bengkulu. Jurnal Geologi Kelautan 1(3): 29-37.

Carter, CH \& DE Guy Jr. 1988. Coastal abrasion: Processes, timing and magnitudes at the bluff toe. Marine Geology 84: 1-17.

Hadi, AI, Suwarsono dan Herliana. 2010 Analisis karakteristik intensitas curah hujan di Kota Bengkulu, FLUX Jurnal Ilmiah Fisika, 7 (2): 119-129

Holthuisen, LH. 2010. Waves in Oceanic and Coastal Waters, Cambridge University Press. $347 \mathrm{pp}$

http://infokotakita.blogspot.co.id/2013/09/wilayah -kota-bengkulu.html diakses 7 Juni 2016

Mei, CC. 1989. The Applied Dynamics of Ocean Surface Waves, Advanced Series on Ocean Engineering, vol. 1.World Scientific Publishing Singapore. 740 pp
Morton, RA. 2004. An Overview of Coastal Land Loss with Emphasis on the Southeastern United Stated. Open File report 03-337, US Geological Survey, Center for Coastal and watershed Studies, St. Petersburg, FL.Retrieved from http:// pubs.usgs.gov/of/2003/of03-337/global.html

Nott, JF. 1990. The role of sub-areal process in sea cliff retreat-southeast Australian example. Zeitschrift for Geomorphology 34:75-85

Schwartz, M. 2005. Encyclopedia of Coastal Science. Department of Geology, Western Washinton University, Washinton, USA. $1213 \mathrm{pp}$

Sunamura, T. 1977. A relationship between waveinduced cliff abrasion and abrasive force of wave. Journal of Geology 85:613-618

Supiyati, Suwarsono \& S. Ichsan. 2011. Angkutan sedimen penyebab pendangkalan Pelabuhan Pulau Baai Bengkulu dengan model diskritasasi dinamika oseanografi. Jurnal Dinamika Teknik Sipil 2(2): 172-180.

Suwarsono, Supiyati dan Suwardi. 2011. Zonasi karakteristik kecepatan abrasi dan rancangan teknik penanganan jalan lintas Barat Bengkulu bagian utara sebagai jalur transportasi vital. Jurnal Makara Teknologi 15(1): 31-38.

Supiyati, Suwarsono \& S Ichsan. 2013. Pola transport sedimen akibat arus yang dibangkitkan gelombang di Pelabuhan Pulau Baai Bengkulu. Semirata FMIPA Universitas Lampung: 91- 97.

Tunas, IG. 2005. Prediksi Abrasi Lahan DAS Bengkulu dengan Sistem Informasi Geografis (GIS). Jurnal SMARTek 3(3): 137-145. 